LBL- -28335

DE90 009204

\title{
Permeability and Dispersivity of \\ Variable-Aperture Fracture Systems
}

\author{
$Y, W, T$ sang and C. F. Tsang \\ Eurth Sciences Division \\ Lawrence Berkeley Laboratory \\ University of California \\ Berkeley, Culiformia 94720
}

January 1990

This wost was supported by the Director, Ofice of Enery Resench, Ofice of Basic Energy Sciences, Enginsering and Geoeciences Division, and by the Direcke, Ofice of Civilian Radioactive Waste Management, Ofrice of Facilities Siting and Development, Siting and Fucilities Technology Division, of the U.S. Department of Energy under Contrect No. DE-AC03-76SF00098. 


\title{
PERMEABILITY AND DISPERSIVITY OF \\ VARIABLE-APERTURE FRACTLRE SYSTEMS
}

\author{
Y. W. TSANG and C. F. TSANG \\ Earh Sciences Division \\ Lawrence Berkelcy Laboratory \\ Liniversity of Califomia \\ Bctkeley, Culitomia $447 \geq 0$
}

(415) 4R6.57R2

\begin{abstract}
A number of noced expertanents huve poined out the need of

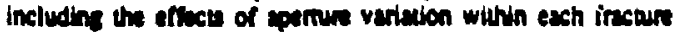

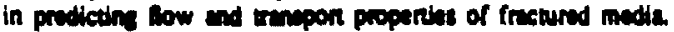

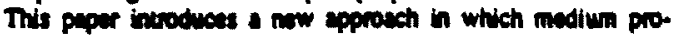
perties, such o the prempebilisy to fow and dispersivity in

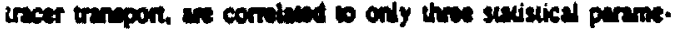

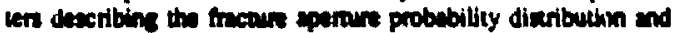

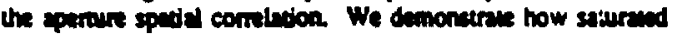

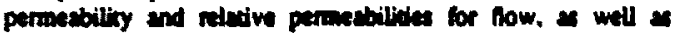

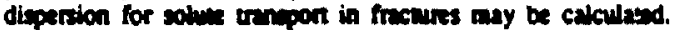
We are in the proces of exrmining the pplictulity of thase

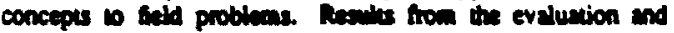
andysis of the nowe Stipn-3D kald den we presented.
\end{abstract}

\section{MTRODUCTION}

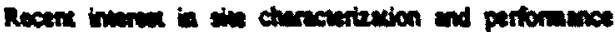

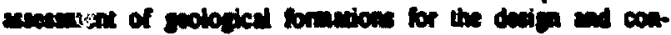

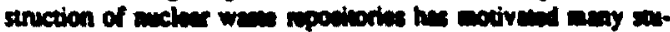
dies of Gild fow and theer tremon in franed rocks. For

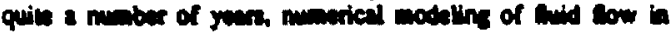

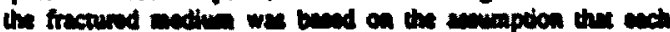

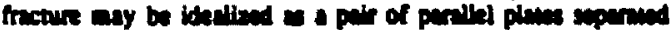

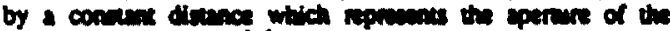

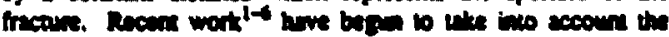

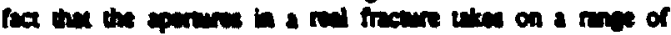

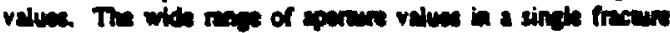

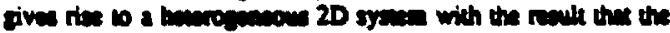

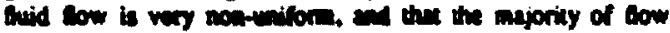

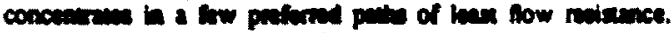

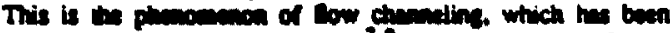

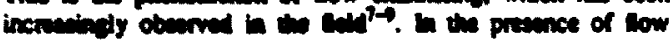

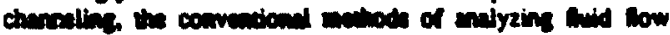

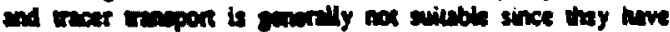

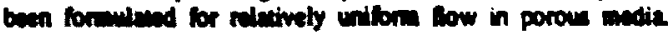

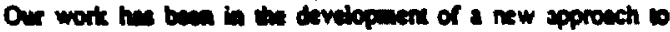

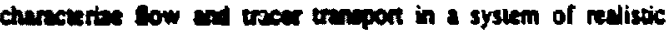

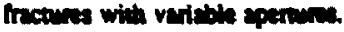

Our aprosech is to consuruct a concepoud model where the madiun propentse such as permabbility b fow and disper.

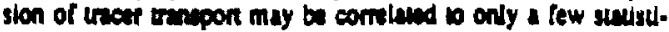

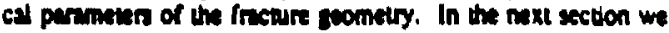

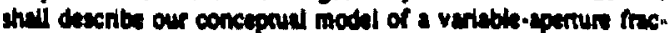

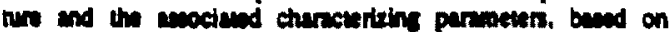

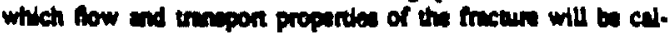

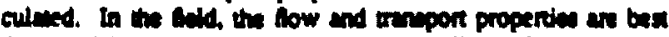

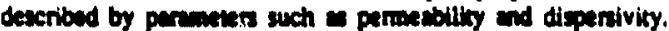
Funtiemos, in the care of multiphese fow in pardally

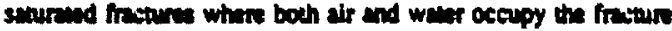
void pace, rivive perwetbilizy curves an nodud in adidon

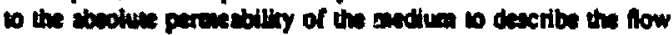

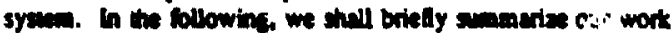

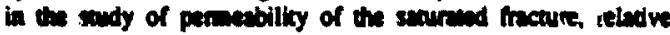

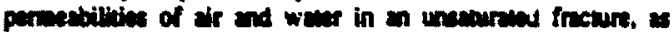
mell on the solus dippentvity. We shall conclude our pupes

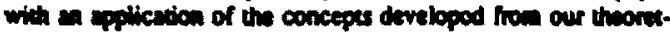
icel sudin to the evelumion and indyois of a set of tracer treneper field den in fincound rocks.

\section{DESCRITION OF A VARLARLE-APERTURE Fucture}

buned of the perlled plen idstizition of a fracture

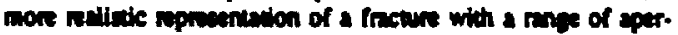

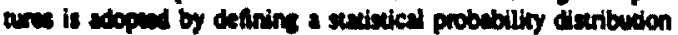

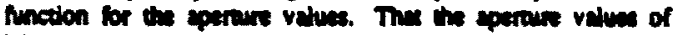

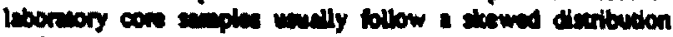

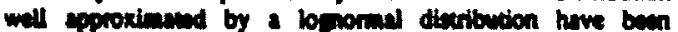

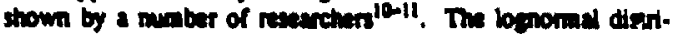
buits of apenues b for b20 is given by:

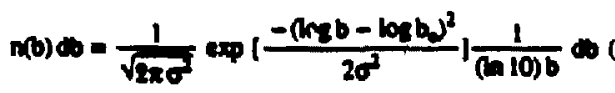

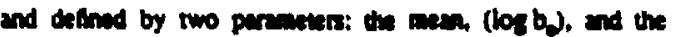
sunderd dovivion, 0 , of the logrithe of cpernes. Now the

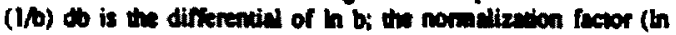

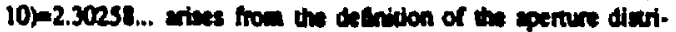
bution on the bave 10 logelita space. The quantity $b_{0}$ is the 
mox probable aperure value and is smaller then the meen aperture $\vec{b}$. Equation 1 is a mahemaical description of an open fracture with zero contact ara between the upper and lower surfaces of the fracture. In generd. rock frocures in-situ are partially closed under stress and have conict ares at which the apertures are zero. Such a partially closed frecure may be represened mathematically ${ }^{\prime}$ by a new distribution obtained from truncaing the original $n(b)$ by $\mathbf{a b}$ and translains the remaining plot 10 the origin. The fractional conect area $(\omega)$ of the frecture $u$ each fracture closure $\Delta b$ is simply

$$
\omega=\frac{\int_{0}^{\Delta b} n(b) d b}{\int_{0}^{\infty} n(b) d b}
$$

where $n(b)$ is sill the sperture diaribution when the liscure surface is in point coniact undet 20 ro applied nomal stress. in Flgur 1 , unseation of the origind $n(b)$ corresponding 10 frac. tiond coniet ane of 15, 25, and 35\% an maked.

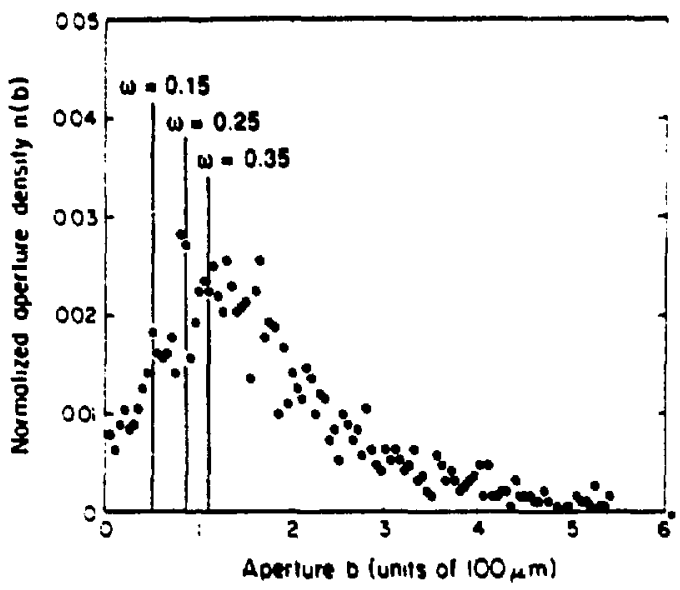

1. Mi. osst

Figure 1. Apomre density distribution n(b) dutived from 10 sets of suxfes roughness profiles of a frecure in Jrain (dua trom Genter ${ }^{10}$ )

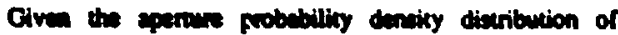

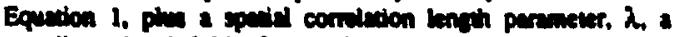

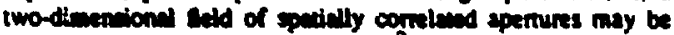

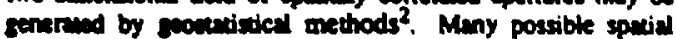
discributione of belizstion of thenes with variable epertures may be emerend by the set of spetifed paraneters: los $b_{4}, 0$ and $\lambda$ Fran 2 show a discreised version of a particuls reslizevion of thanue eperanes, with $\log b_{0}=1.7,0=0.43$ and $\lambda=0.2 \mathrm{~L}$ where $\mathrm{L}$ is the linem dimension of the single fracture. The meribudes of the epetwirs are indicated by shading, with listeret shading correspondine to larger aperures.
In this paper we shall show resule for fractures which have isouropic spetial comelation: sudies for sysuems with different values of $\lambda$ in onhozonal directions may be found in Tsang and Tsan's and Pruess and Tsang ${ }^{12}$.

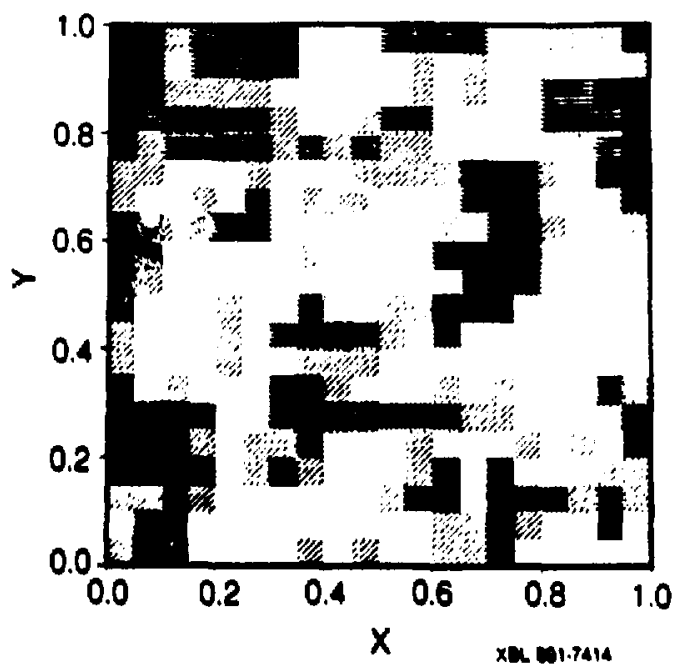

Figure 2. Statistically genernted apertures with a spatial correlution length $\lambda$ of $0.2 \mathrm{~L}$ in the plane of a single fracture of linear dimension $L$. The shadings are given in five levels from small apertures (dark) to large ones (white).

\section{SATURATED FERMEADLITY OF A SLNGLE FRACTURE}

Assuming the Darcy's law spplies beally for a fracture with a ringe of speraires such as shown in Figure 2, then the locel permesbility in a water-sanuraed variable-apenure fracure is proportions wo the square of the local aperture and is thus strondy vering in space. Thus the permesbility value from a singls point powers bow mesurement will be a strons func. ton of the nisemusent posilion for a panicular reslizesion of frecurs eperene dicribudon. Furthermore, the pemesbility

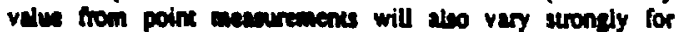
difienom molization of fretures chanceatized by the sane perriesters $\log _{0} b_{0}, \sigma$ and $\lambda$. However. if we consider how and presens trom a line boundery of the fincure to the line boundery on the oppodic sids, when the line covers severd speid combinion lenphs, it is possible to define a permesbility the is independent of satioticel realizsions. Let us start with a sinjle fremire such as shown in Figure $\mathbf{2}$ and apply constant prespurs, $P_{1}$ and $P_{2}$, on two opposice sides while mainuining the remsiring wo sides of the fracture to be no-flow boundaries. The fluid flowrie through the frecture can be calculated by solving a matrix equation relaing the pressures at all points in the frecture. The sururced permestility of the frecture, $k_{s}$. is then given by the cotal howre from one boundary line to 
the outer divided by the pressure diffenence across the fracure. Calculatione using many relizabions have shown tha $k_{3}$ is defined within a factor of two for specified $b_{0}, \sigma$, and $\lambda$, and that it is insensitive $\omega \lambda$ if $\lambda$ is less then $20 \%$ or $30 \%$ of the size of the 2D flow region. The values of $k_{\text {, }}$. however. is sensitive to the apernure distribution, i. e.. the values of $b_{0}$ and $\sigma$.

We have studied' the dependence of the samurced permeability on aperare probsbility distribution in the concext of parially closed fractures with differen consact axes $\omega$. 25 defined in Equation 2. The calculacion was carried out for the aperure probability distribution function and three different $\omega$ values shown in Figure 1 . We may express the resuls as ratios to the permeability. $\vec{k}$, of a frecture in the fardiel-place approximalion. having a consank sperture valuc tqual to the mean sperwre of a fiachure such as shown in firure 2. We found the the rato $k_{a} / \vec{k}$ is -0.1 when the fracture contact ares $\omega$ is 15\%: 0.04 when $\omega$ is 25\%, and 0.01 when $\omega$ is $35 \%$. Our resules, logether with confirming experiments oburvelions by Abelin et al", undatin the sinificen role played by andl apernure in a variblesperme frense on low permesbiliky, and the pitfell of incepreding pefmesbliky mensurements in tems of idealied parilel-pive frectures.

\section{RELATIVE PERMEADILITY CURVES FOR UNSATURATED FMCTURES}

For unsururied frectured rocts such as the uff formesion at the propesed reposilory sic a Yucen Mountain, portion of the fracture pore space may be sunurad with waef and the res occupied by air or ges phes. The phese occupelion depends on wrer-eir cepillery poeaure tiven by $P_{c}$ a

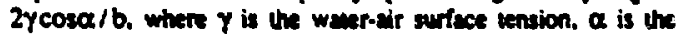
contact aple between the waer meriscus and the fracure walls (asenined of be zero in our can), and b is the locel frec. ure apermure value. Wast fow is excluded forn the aip. occupied portion and reteive penmesbility for werer depends on connected wam-occupied portion in the varisble-cperane frecture.

To calculen the reletive pentecbility of water fow, we stan with a dscretized version of a verible-iperture fracture (Figure 2) and atine culof eperture $b_{c}$ corresponding ba capillary pessure $P_{c}=2 \gamma / b_{c}$. All sccessible spertures imalier then $b_{c}$ ve occupied with weet and all larget apertures with air. The water surusion of the frcture $S_{w}$ which correponds to the cueff cepillary presere $P_{c}$ is obvined by directly summing the water sentend pore volume. As in the lax section on the deverninum of permesbility, a preseure difference is applind scroes two opposits boundaries of a single fracture and the Auld fow in celculend for a netwotk of water-oceupied frecon elenets. The stedy fowrice obtained will yield the effective wher peruetbility. A similer simuluon with the Inger b velues which an occupied by ait will yield the efrective sit pamembilicy. The bove procedure asumet the the preseure grodien is not sizesble so tha the two-phase problen in the fmenure plane will separate inso iwo separie single-phwe problem, which means the the intion between fluid and frecoure walls dominues over fncium between the two flowing phases. Division of the effective permeability cal- culared above by the single phase permeability (when all apertures in the fructures are occupied) yieids the relative permea. bility a each sarurtion $S_{w}$. Details of the work may be found in Pruess and Tsank 12 .

An example of the relative permeability curves thus calculared for the frecrure of Figure 2 is shown in Figure 3. Figure 3 shows in apparenty strong interference between the water and air phases with an exuremely large immobile air phase suxuration of abouk 84\%, and the range of stauration values in which both air and water phases are mobile is virually non-existen. This arises because a contiguous flow palh for uir can only be meinkined when in addition 10 all the large aperiures some of the small spertures also conisin the ulr phase. In other words. a relatively large air saturation is required before aif can flow. Our simulations show that this strong interference between the two phases in two-dimensional how in fractures persists unless there are long-range spatial correlution enons epertures in the direction of flow; then the immoble air phace surrution decreset and there is a range of saurtion valus in whleh both air and water phise an lowing. The chove retules demonstrate the imponance of the

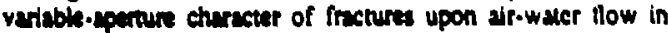
unswured sysioms, and mote experiments work in the laboriory and in the lield is needed to study such systems.

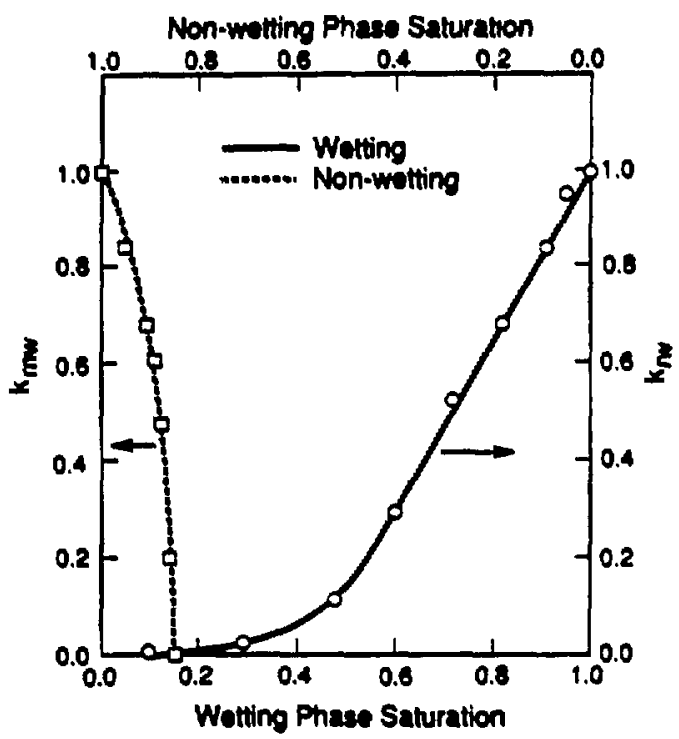

xis entrow

Figure 3. Simulated wetting (water) and nonwetting (aif) phase relative permeabilities for the spaial aperture distribution of Figure 2. 


\section{TRACER TRANSPORT W VARIABLE-APERTURE FRACTURE}

Tracer residence times and dispersion are important properties which chancterize transpon in finctured rock masses. In this section we describe the numerical calculation of the tricer breskthrough curves for transpon in fractures. Surting with a variable-aperture frocture (e.g. Figure 2) sanurned with water. fluid flow from a consant bigh pressure line boundary to the bower pessure boundary on the opposice side is calculaced as before. The local flowrues a different points in the fracture are found w vary over several onders of magnitudes. To display the variation of the larfe range of flowrales over the entire frecturs, the relative volumetric flowrates are ploked in Figure 4 for four realizations of the single fracture when the thickness of the lines varies as the square root of the fowrice. We have cartied out this kind of simulation for many ralizations of the frecture 2 . We found that the now patkems always display perferned puh of lare volumeuric towraces the ase formed becaues of the varition of the spernires within

a) Run 511

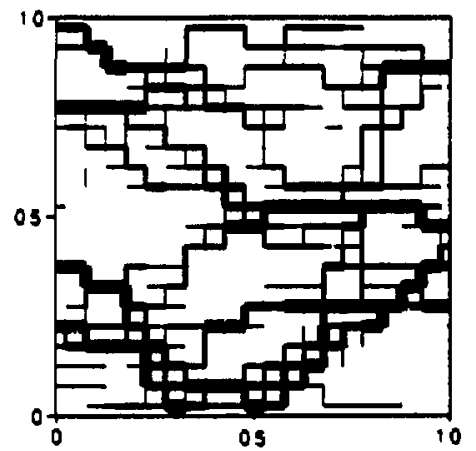

c) Run 513

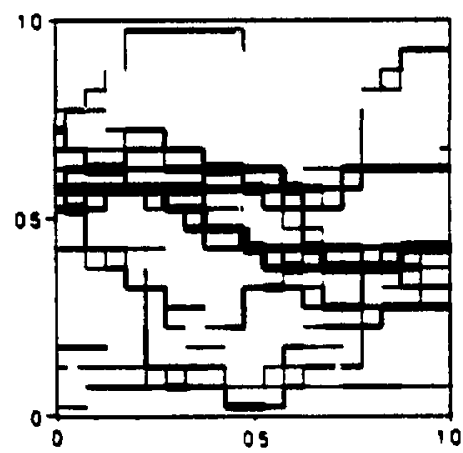

the single fracture plane, and that there is a tendency for all the fow pahs with large towrates to coulesce into "channels" over \& widh on the order of one spatial correlation lengh. The specing between these large howrite "channels" is also on the onder of the spatial correlation length of the fracure apertures.

Staning with distributions of fowrates over a variableapernure fracture, solute transpon phenomena are investigated by tracking the particles advected through the fracture. For each realization as shown in Figure 4, particles are let in at the lett hand (higher constan pressure) bounday and collected at the righe hand (lower constun pressure) boundary. Plots of the number of paricles collected all alle outets on the righ hand boundary as a function of arrival times, i.c., tracer break. through curves, are shown in Figure 5. Seven calculaed break. through curves are shown, four are for the fractures shown in Figure + with $\lambda=0.1 \mathrm{~L}$, and three are for additional realiza. tions with $\lambda=0.4 L$. In general, the breakthrough curves of tecer transport in two dimensions through these variable.

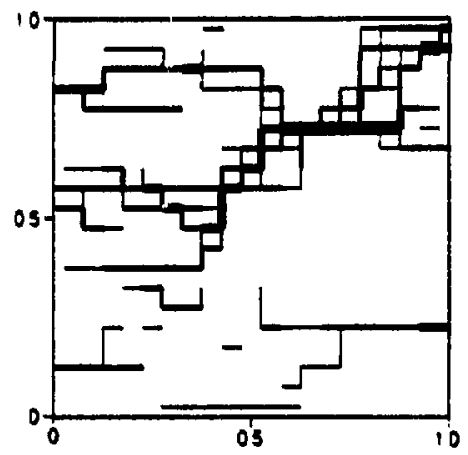

d) Run 514

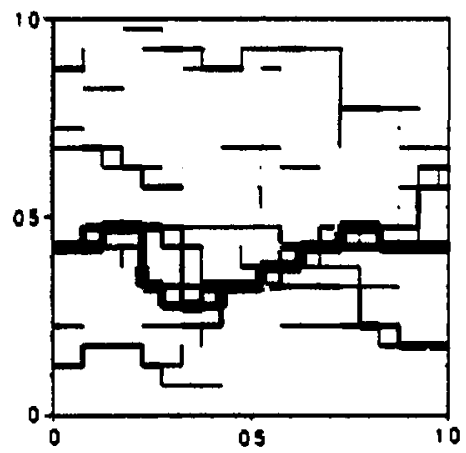

XBL 875.9570

Figure 4. Fluid Alowrates for iour realizations of the variable-aperture fracture with pressure cratient applied left to right. The thickness of the lines is propontional to the square root of the Hourate for each case. 


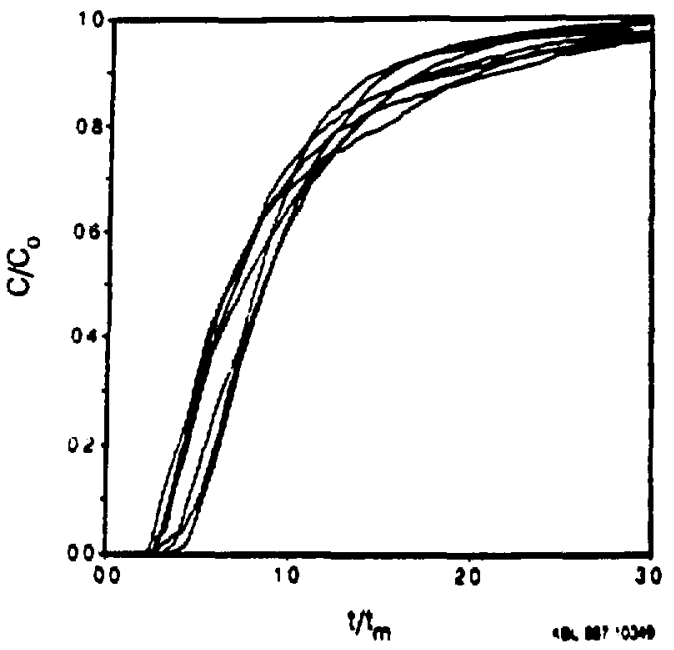

Figure 5. Seven tracer brukthrough curves from parti. ck becking with time normuliand to respec. tive mean residence time, ho of all the parti. cles.

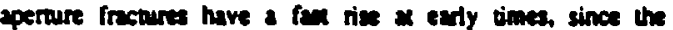
majority of percicias cake the far sow paths. Then, thene is a tone tiil in the beskthough arve deve to small traction of pericles menderine through the frecture, including in theite

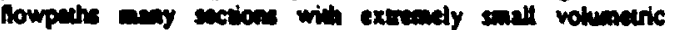
fowremes. In this frous the dime axis ha been nomalized o

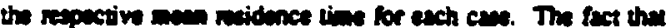
these seven curve fall within a narrow bend of exch oter indicaves thin the dispension dieplayed by these bestethrough curves. : anemend by the nitio of the difference of sor and

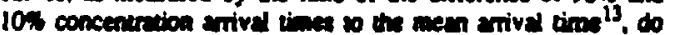

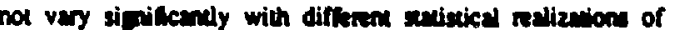

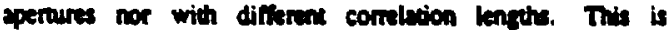
because these beskthrough curves involve the residence timen

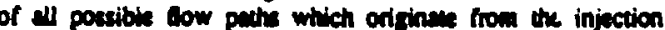
line on the len boundary and uminis on the exie line of the righe boundary, and boch boundaries cover severd comelaion lengths. Thus to information copenined in the beckethrough

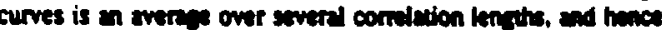

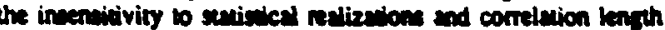

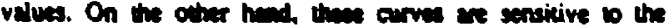

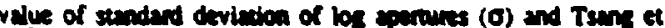

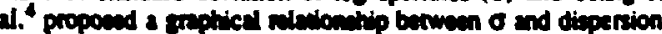

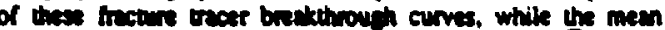

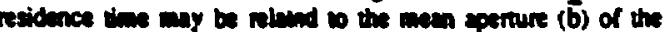
fractur.

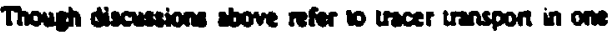

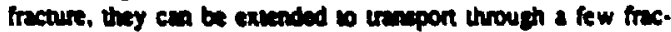

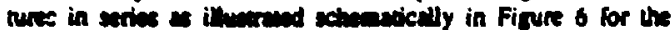
sace of the comenend frecurne. This picture may be velid when the trumpor dietunce coress only a lew specings between conducting frecures. For such a case. the sbove dis.

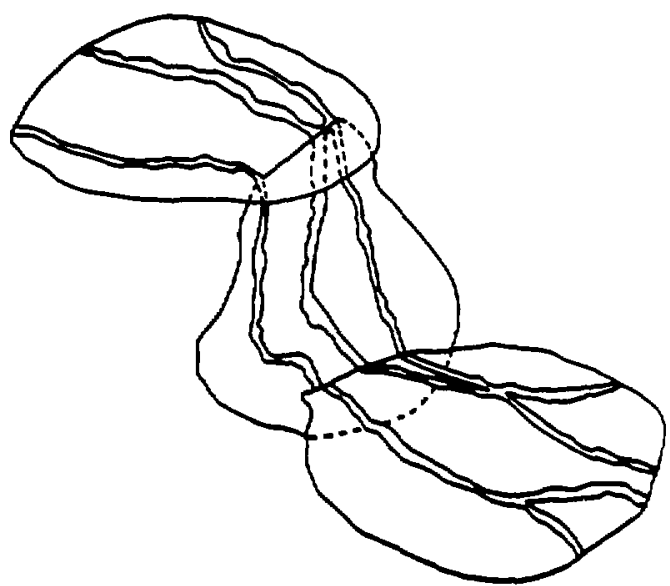

1A. $49+9$

Figure 6. Schematic diagran of channelized now in three connected variable-aperture fractures.

cuscion for one tructure will still apply. In the study of held den (nexs metion), the spacing of conducting fructures versus trecer tranpon distunce is such the the pletere (Figure 6) correaponding to a few fractures asy still be valid.

\section{APrLKATION TO FELD DATA}

The concapts developed in the theoretical saudies

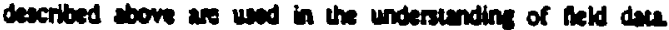

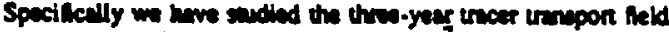
experinenen by Newonicks and coworkers ${ }^{7}$ in the Stripe mines. Sweden (Suipe 3D experinem). A drith in Stripe, $75 \mathrm{~m}$ lon: and $4.5 \mathrm{~m}$ wide and boure $2.5 \mathrm{~m}$ high, was uned for the expert. ment. The roof and will of the drif were covered by over $3001 \times 2$ an platic shaets for collection of wase and uscers. Nine differen treass were injected ine nine zones of high conductivity in thre 75-m verical bontholes drilled $x$ three locitione ins the roof. Apperent rucer usaspon disunces from the injection locucions to the collection sheit ranse from $10 \mathrm{~m} 45 \mathrm{~m}$.

$k$ wes found thit even though the drif well eppeas to be covend with any fractum. only a fration of the colloction

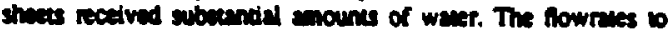
the differem collection shate vary over severd onders of mas. nimade. This to to be expecied from the theoretical suidies dascribed cbove (Figures 4 and 6). During the firs 30 mondhs,

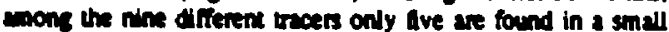
percantare of the collection sheets. The brekthrough curves from the live tracers thil arrived a different colvection sheets are shown in Fifure 7. For each case in this tigure we have plowed only the eady-lime pert of the dan. since des for laver 


\section{Stripa 3-D Data}

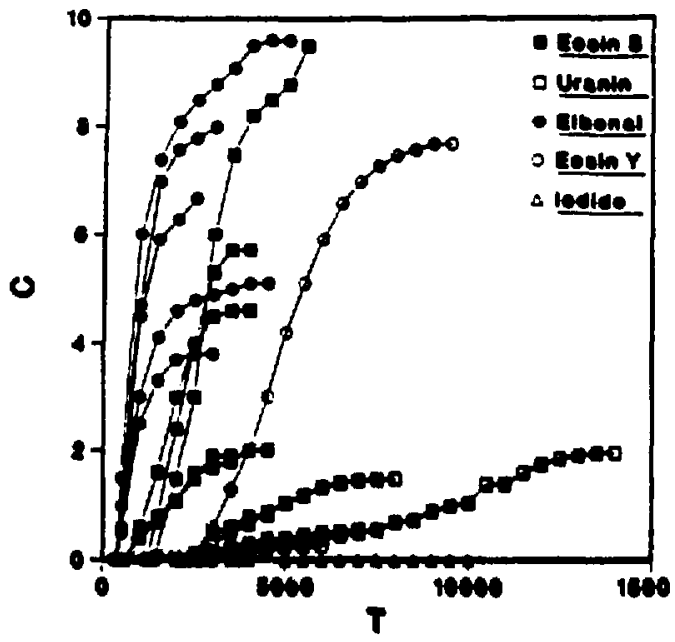

xace anowing

Figure 7. Tracer brekthrough curves from Sxipa-3D fisld experiment Dan are included menly up 10 the fin "plamau" beyond which effects of injection flowren fuctuntions become dowinent.

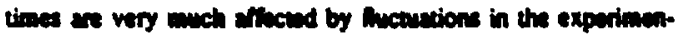
w treser injection lowrom. Thes curves heve very diflertent

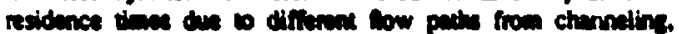

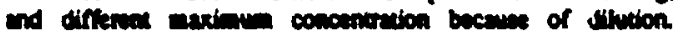
However, whon we plot thom with theer concenterition normal-

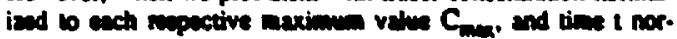

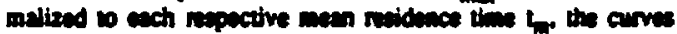

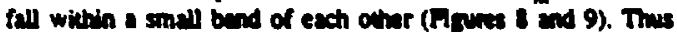

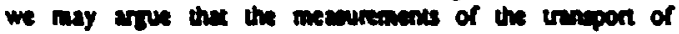

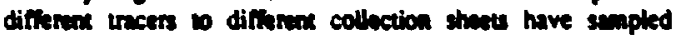

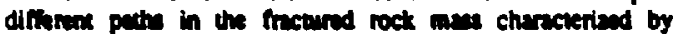

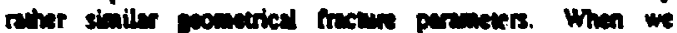
andyed the dipenion thon the brelectrough den shown in Figure 8 and 9, we arive an a dispenion versul diences plot pive in Fipe 10. Hexe the dipenion is charcierized ${ }^{3}$ by ithe resio of $\left(b_{0}-t_{0}\right)$ bo ton with $h$ beine the time when the

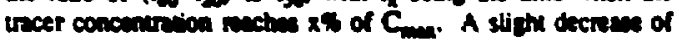

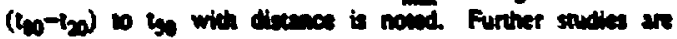

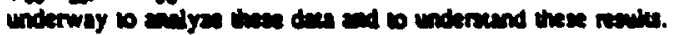

\section{SUMOMARY AND CONCIUSBONS}

A nuber of nate experionents have poinsed ou the

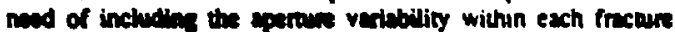
in pudicting tow and trapon popenties of fractured medil.

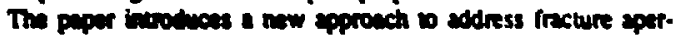

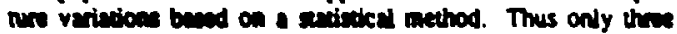

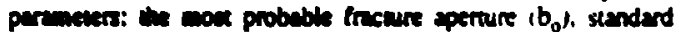

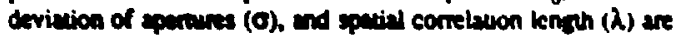

\section{Stripa 3-D Data}

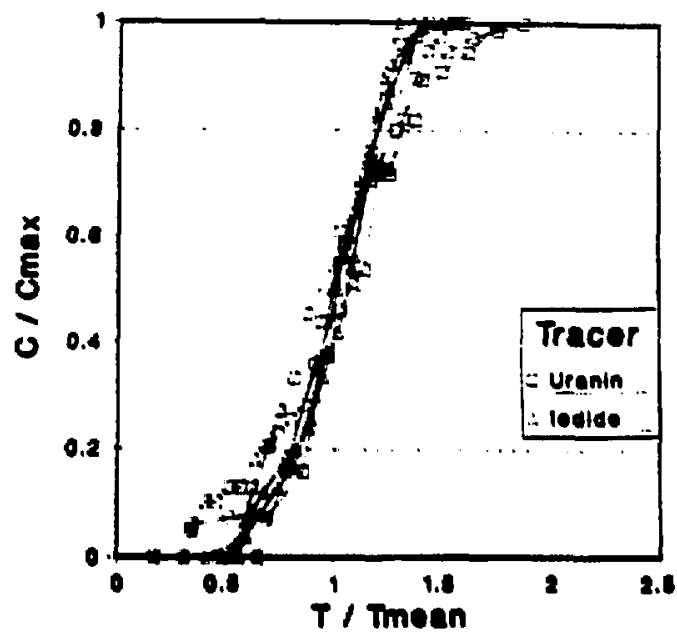

ax M(-)

Figure 8. Tracer breakthrough curves for uranin and lodide with apparent transport distance rangins from $20.40 \mathrm{~m}$.

\section{Stripa 3-D Data}

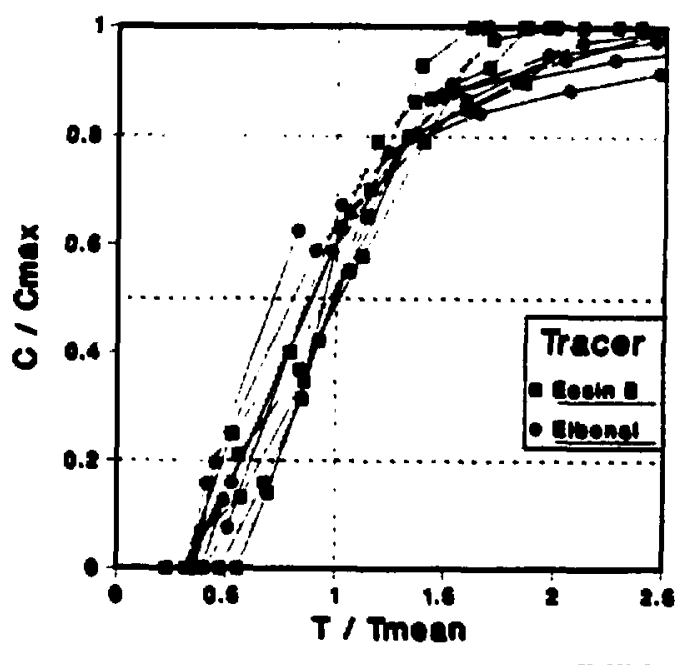

$\operatorname{coc}$ พ01-2

Figure 9. Trucer beakthrough curves for eosin B and elbunol, with spparent orenspon distance raging from $10-20 \mathrm{~m}$. 


\section{Stripa 3-D Data}

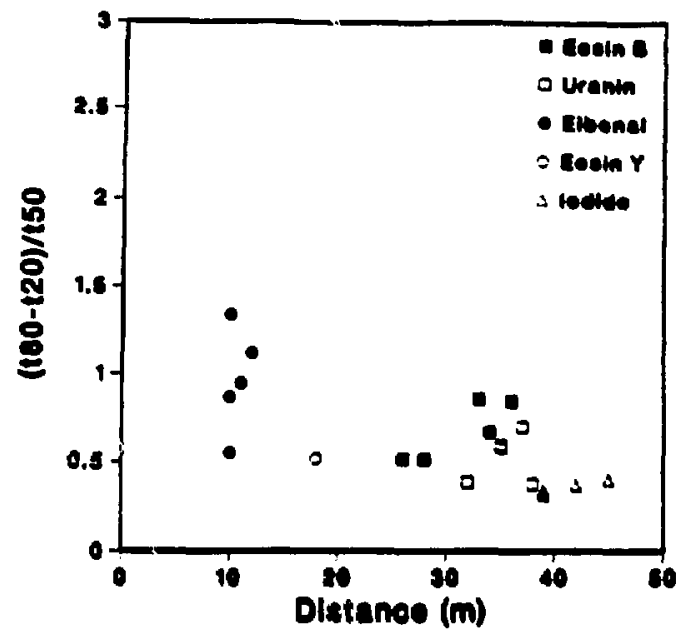

1610-3764

Figure 10. Dispersion as defined by $\left(t_{00}-t_{20}\right) / t_{50}$ versus apperent trensport distance for all 5 urecess.

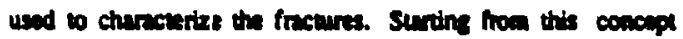

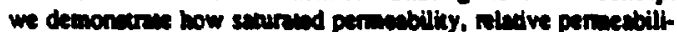
ties and solme dipsrion of the frecensen can be calculand. We axe in the procenos of cpolyins these resilus and concepses to the undersuding of cals dace.

\section{ACKNOWLEDGMIENTS}

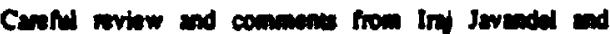

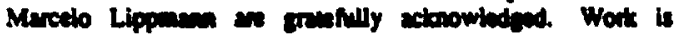
joindy suppond by the Dinctor of Ortes of Enory Revench.

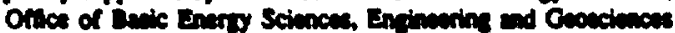
Division. and by Dirwer. Ortoe of Civlina Redionetive

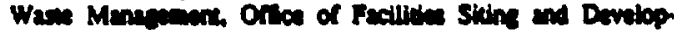

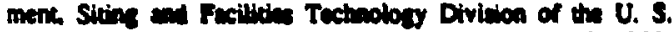

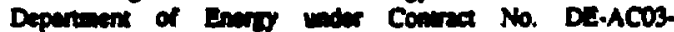
765 rooves.

\section{REFERENCES}

1. Y. W. TSANG. The Eese of Tomosily of Fluid Fow thouth a Sinets Precturs," Weser Resowr. Res.. 20. (9). $1209 \cdot 1215$ (1944).
2. L. MORENO. Y. W. TSANG, C. F. TSANG, F. V. HALE and I. NERETNIEKS. "Flow and Tracer Transport in a Single Fracture: A Stochastic Model and its Relation to some Field Observation," Waver Resowr. Res., 24. (12). 2033 -2048 (1988).

3. Y. W. TSANG and C. F. TSANG, "Channel Model of Flow through Fractured Media." Warer Resour. Res.. 33. (3), +67-479 (1987).

4. Y. W. TSANG, C. F. TSA.NG, I. NERETNiEKS and L. MORENO. "Flow and Tracer Transpon in Fractured Media: A Variable Apermure Channel Model and is Properies." Water Resow. Res.. 24. (12). 2049-2060 (1988).

5. Y. W. TSA.VG and C. F. TSANG, "Flow Channeling in a SinHile Fracture as a Two-dimensional Strongly Heterogensous Permoable Medium," Hoser Resow. Res., 25. (9), 2079-2080 (1989).

6. S. R. BROWN, "Fluid Fow through Rock Joints: the Elrett of Surface Roustness," Jowr. Geophys. Res., 92. (B2), 1337-1347 (1917).

7. I. NERETNIEKS, "Tranepon in Frectund Rocks," Proceed. ings. Mecmoses of the 17th Invernational Congress of insernationd Assecievion of Hydralogistr, (17), 301.311, Inesmationd Ascociation of Hydrotogists, Tuecon, Atiz. (1945).

8. H. L. AULLN, L. BERGERSSON, I. GIDLUND, L. MORENO, I. NERETINIEKS, H. WIDEN and J. ANDERSSON, "Reaules of some Lare Scale in Sity Tracer Experiments in a Drit a the Stripe Mine." Proceselings of Invernetional Conference on Fluid Flow in fractured Rocks. Ausnter Georgia. May 16.11 (19t8).

9. 7. 1. DoURke, "Chmeling of Flow through Frectures in Rock." Proceedings of GEOVAL.87, Ineernational Symposium. Stockholm, Sweden, April 7.9 (1967).

10. S. GENTLE. "Morphologie et Comporument Hydrome. canique d'une Frecture Narurelle dans un Granite Sous Contrine Normsls," Doctoril Thesis. U. d'Orkens. France (1986).

11. J. E. OAL, "Comperien of Coupled Precture Deformesion and Fuld Fow Models with Dinet Memurements of Fracture

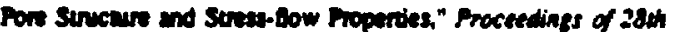
U. S. Sympodine of Rock Mechavics, Tuecon. Atizona 29 Jure. I wly. 1213-1222 (1957).

12. K. PRUEess an Y. W. TSANG, "On Two-phere Retrive Pennecbilly and Cepiling Premun of Rouph-walled Rock Prectures," accepend to publicuion in Wenr Resow. Ras., (1990).

13. I. NERETNEISS. T. ERIKSEN and P. TÄHTLNEN, "Tracer Movemem in a Single Fismen in Grndic Rock: Some Experi. mentel Reauks and their (nverpretution." Waser Resowr. Res., is. (4), Ese-858. (1942). 


\section{DISCLAIMER}

This document was prepared as an acount of work sponsored by the United Sules Government. Neither the United Sutes Government not any wency thereof, nor The Resents of the - University of California, nor any of their employees, makes any warranty, express or implied. of assumes any keal liability or responsibility for the eccurecy, completeness. or usefulnes of any information, apparatus, product, or process dixclosed, or represents that its use would not infrine privately owned riehts. Reference herein to any specific commercial products process. or service by its trade name, trademark, manufecturer. or otherwise, does not necessarily constiture of imply its endorsement, recommendation, or favorins by the Uniked Sutes Government or any arency thereof, of The Resents of the University of California. The views and opinions of authors expressed here in do not necessarily stste of reflect those of the United Stsies Government of any acency thereof or The Rewents of the University of California and shall not be used for advertising or product endorsement purposes.

Lawrence Berkeley Laboratory is an equal opportunily employer. 